\title{
Troglitazone reduces hyperglycaemia and selectively acute-phase serum proteins in patients with Type II diabetes
}

\author{
P. Ebeling ${ }^{1}$, A.-M. Teppo ${ }^{2}$, H.A. Koistinen ${ }^{1}$, J. Viikari ${ }^{3}$, T. Rönnemaa ${ }^{3}$, M. Nissén ${ }^{4}$, S. Bergkulla ${ }^{4}$ P. Salmela ${ }^{5}$, \\ J. Saltevo ${ }^{6}$, V. A. Koivisto ${ }^{1}$ \\ ${ }^{1}$ Division of Internal Medicine and Geriatrics, Department of Medicine, Helsinki University Central Hospital, Finland \\ ${ }^{2}$ Division of Nephrology, Department of Medicine, Helsinki University Central Hospital, Finland \\ ${ }^{3}$ Department of Medicine, Turku University Central Hospital, Finland \\ ${ }^{4}$ Department of Medicine, Vaasa Central Hospital, Finland \\ ${ }^{5}$ Department of Medicine, Oulu University Hospital, Finland \\ ${ }^{6}$ Department of Medicine, Jyväskylä Central Hospital, Finland
}

\section{Abstract}

Aims/hypothesis. Inflammation could play a part in insulin resistance. Thiazolidinediones, new antidiabetic drugs, possess anti-inflammatory effects in vitro. We investigated if acute-phase serum proteins are increased in patients with Type II (non-insulindependent) diabetes mellitus who had been treated with insulin and whether troglitazone has anti-inflammatory effects in vivo.

Methods. A total of 27 patients (age $63.0 \pm 1.7$ years, $\mathrm{HbA}_{1 \mathrm{c}} 8.8 \pm 0.3 \%$, BMI $32.7 \pm 0.8 \mathrm{~kg} / \mathrm{m}^{2}$, duration $15.2 \pm 1.4$ years, insulin dose $73.3 \pm 7.0 \mathrm{U} /$ day) participated in the study. The patients received daily either $400 \mathrm{mg}$ troglitazone or placebo for 16 weeks. Blood samples were taken at baseline, at the end of therapy and after a follow-up time of $23 \pm 4$ days.

Results. The concentrations of serum amyloid A $(6.2 \pm 1.1 \mathrm{mg} / \mathrm{l})$ and C-reactive protein $(6.1 \pm 1.1 \mathrm{mg} /$ l) were increased $(p<0.001)$ and complement protein C3 (1.69 $\pm 0.05 \mathrm{~g} / \mathrm{l})$ was also above the reference range for healthy subjects. Placebo treatment had no effect on glucose or inflammation, whereas troglitaz- one reduced fasting glucose (from $10.4 \pm 0.6 \mathrm{mmol} / \mathrm{l}$ to $8.1 \pm 0.5 \mathrm{mmol} / \mathrm{l}, \quad p<0.01$ ), $\mathrm{HbA}_{1 \mathrm{c}} \quad$ (from $8.7 \pm 0.3 \%$ to $7.5 \pm 0.3 \%, p<0.01)$, insulin requirements (from $75 \pm 10$ U/day to $63 \pm 10$ U/day, $p<0.05$ ), serum amyloid A (from $6.3 \pm 1.5 \mathrm{mg} / \mathrm{l}$ to $4.0 \pm 1.3 \mathrm{mg} / \mathrm{l}, \quad p=0.001), \quad \alpha-1$-acid glycoprotein (from $906 \pm 51 \mathrm{mg} / \mathrm{l}$ to $729 \pm 52 \mathrm{mg} / \mathrm{l}, p=0.001$ ) and $\mathrm{C} 3$ (from $1.72 \pm 0.07 \mathrm{~g} / \mathrm{l}$ to $1.66 \pm 0.06 \mathrm{~g} / \mathrm{l}, p<0.05$ ) but not $\alpha$-1-antitrypsin, ceruloplasmin, C-reactive protein or haptoglobin significantly. Concentrations of glucose and acute-phase reactants had returned to those before treatment at the follow-up visit.

Conclusion/interpretation. In Type II diabetic patients serum amyloid A and complement protein C3 are raised. Troglitazone exerts a selective reversible action on some acute-phase proteins and C3 but not on others in conjunction with the improvement in glucose metabolism. [Diabetologia (1999) 42: 14331438]

Keywords Type II diabetes, inflammation, troglitazone, hyperglycaemia, serum amyloid A, complement protein C3.
Received: 31 May 1999 and in final revised form: 3 August 1999

Corresponding author: Pertti Ebeling, MD, Helsinki University Central Hospital, Department of Medicine, P. O. Box 341, FIN-00029 HYKS, Finland

Abbreviations: A1GP, $\alpha$-1-Acid glycoprotein; C3, complement protein $\mathrm{C} 3$; CRP, C-reactive protein; PPAR, peroxisome proliferator-activated receptor; SAA, serum amyloid A; SAP, serum amyloid $P$ protein; sTNFRII, soluble tumour necrosis factor- $\alpha$ type II receptor.
Recent evidence suggests abnormalities in the inflammatory factors in Type II (non-insulin-dependent) diabetes mellitus. Increased concentrations of haptoglobin, $\alpha$-1-acid glycoprotein, C-reactive protein (CRP), serum amyloid A (SAA) and interleukin-6 have been reported in Type II diabetes or in impaired glucose tolerance $[1,2]$. In addition, atherosclerosis, which is often associated with Type II diabetes, is increasingly considered to be a chronic inflammatory disease [3]. Insulin resistance is associated both with Type II diabetes and with cardiovascular disease. The inflammatory cytokine tumour necrosis 
factor- $\alpha(\mathrm{TNF}-\alpha)[4]$ and the complement protein $\mathrm{C} 3$ concentrations [5] are closely related to insulin resistance and obesity.

Thiazolidinediones are a new group of pharmaceutical agents, with both glucose and lipid lowering effects and the ability to reduce insulin resistance [6, 7]. Thiazolidinediones possess affinity for peroxisome proliferator-activated receptor (PPAR) $\gamma$ [8-10]. A positive correlation exists between the PPAR $\gamma$ activity and the antidiabetic responsiveness [11]. Recent in vitro data suggest that thiazolidinediones inhibit the production of inflammatory cytokines as well as downstream markers of inflammation such as nitric oxide produced by monocytic cells [12, 13]. Data from the Wistar fatty rats show that the antidiabetic and lipid lowering action of a thiazolidinedione (pioglitazone) is associated with the suppression of TNF- $\alpha$ production [14]. Recently the relation between PPAR $\gamma$ and inflammation has become the focus of great interest [15]. We are not aware of any data in humans concerning the effect of thiazolidinediones or any other specific agonist for PPAR $\gamma$ on inflammation. Consequently, in the present study we examined the effects of troglitazone on various positive (SAA, CRP, $\alpha$-1-acid glycoprotein (A1GP), $\alpha-1$ antitrypsin, $\mathrm{C} 3$, ceruloplasmin, haptoglobin) and one negative (albumin) acute-phase serum proteins and glucose and lipid homeostasis in patients with Type II diabetes.

\section{Subjects and methods}

Patients. A total of 27 patients (11 men, 16 women) with Type II diabetes who had been treated with insulin from five Finnish centres (Helsinki, Turku, Vaasa, Oulu and Jyväskylä) participated in this study, which was a part of a large international troglitazone trial. Patients were included, if their age was over 35 years, duration of diabetes was over 1 year, daily insulin dosage was 20 or more and less than 150 units, $\mathrm{C}$ peptide was more than $0.3 \mathrm{nmol} / \mathrm{l}$ and they had $\mathrm{HbA}_{1 \mathrm{c}} 7.0 \%$ or more at the screening visit. Oral antidiabetic treatment was not allowed. The mean $( \pm \mathrm{SEM})$ age was $63.0 \pm 1.7$ years, $\mathrm{HbA}_{1 \mathrm{c}}$ $8.8 \pm 0.3 \%$, body mass index $32.7 \pm 0.8 \mathrm{~kg} / \mathrm{m}^{2}$, diabetes duration $15.2 \pm 1.4$ years, insulin dose $73 \pm 7 \mathrm{U} /$ day. Most patients (twelve in the troglitazone and ten in the placebo group) used concomitant medication during the study with no clear differences between the groups. These medicines consisted mainly of angiotensin converting enzyme inhibitors, beta blockers, calcium channel blockers, long-acting nitrates and low dose (50 to $150 \mathrm{mg} / \mathrm{d}$ ) aspirin prescribed for hypertension and cardiovascular diseases.

Design and methods. The study was planned to compare the effects of a 16-week treatment of troglitazone ( $400 \mathrm{mg}$ once daily) with placebo in Type II diabetic patients on insulin therapy alone. As baseline the patients were assigned to randomization 4 weeks after the screening visit in a double-blind fashion to either troglitazone or placebo treatment and they visited the clinics at 4 week intervals. During the clinical visits the insulin doses were adjusted to meet the metabolic requirements of
Table 1. Characteristics of the patients at randomization ${ }^{\mathrm{a}}$

\begin{tabular}{lll}
\hline Characteristics & Placebo & Troglitazone \\
\hline$n$ & $12(6 / 6)$ & $15(5 / 10)$ \\
Age (years) & $63.5 \pm 2.8$ & $62.6 \pm 2.2$ \\
BMI $\left(\mathrm{kg} / \mathrm{m}^{2}\right)$ & $33.1 \pm 1.0$ & $32.3 \pm 1.3$ \\
Diabetes duration (years) & $14.3 \pm 1.9$ & $15.9 \pm 2.1$ \\
Fasting plasma glucose & & \\
(mmol/l) & $12.2 \pm 0.9$ & $10.4 \pm 0.6$ \\
HbA $_{1 \mathrm{c}}(\%)$ & $8.8 \pm 0.3(n=9)$ & $8.7 \pm 0.3(n=12)$ \\
Insulin dosage (U/day) & $75 \pm 10$ & $72 \pm 10$ \\
\hline
\end{tabular}

a There are no significant differences in any of the characteristics between the two groups

the patients. Other medication was kept practically unchanged during the study. Blood samples were drawn at the screening visit for $\mathrm{HbA}_{1 \mathrm{c}}$ and $\mathrm{C}$ peptide screening measurement in the central laboratory. At baseline, at the end of the 16-week treatment period and after the mean follow-up time of $23 \pm 4$ days blood samples after an overnight fast were taken for this substudy for measurements at the research laboratory of Helsinki University Hospital. The study was approved by the ethics committees of each participating centre. Each patient gave his/her written, informed consent and the study was conducted according to the rules of good clinical practice.

Methods. Fasting plasma glucose concentration was determined using glucose oxidase method (Beckman glucose analyzer, Beckman Instruments, Fullerton, Calif., USA). Serum $\mathrm{C}$ peptide, total and HDL-cholesterol and triglyceride concentrations were determined as described previously [16]. Haemoglobin $\mathrm{A}_{1 \mathrm{c}}$ (reference range $\left.4.0-6.0 \%\right)$ at baseline $(n=21)$ and at the end of the treatment $(n=26)$ were determined with a DCA 2000 analyser (Bayer Diagnostics). Serum apolipoprotein A1 (apoA-I) and apolipoprotein B (apoB) were determined by commercially available kits (Orion Diagnostica, Espoo, Finland). Serum albumin (reference range 36.1-47.5 g/ 1 for men and 34.8-46.1 g/l for women) was measured with automated Bromcresol Purple method (Hitachi 917, Tokyo, Japan). Serum haptoglobin (reference range 0.29-2.00 g/l), $\alpha-1$ acid glycoprotein (A1GP) (reference range 500-1200 mg/l), $\alpha$-1-antitrypsin (reference range $0.98-1.78 \mathrm{~g} / \mathrm{l}$ ), ceruloplasmin (reference range $200-550 \mathrm{mg} / \mathrm{l}$ ) and complement C3 protein (C3) (reference range 0.7-1.6 g/l ) concentrations were determined with automated immunoturbidimetric methods (Hitachi 911). Serum amyloid A protein (SAA) was measured by enzyme immunoassay (Cytoscreen, Biosource International Calif., USA), C-reactive protein (CRP) by radioimmunoassay as described previously [17]. The detection limit for SAA is $0.005 \mathrm{mg} / \mathrm{l}$ and for CRP $0.05 \mathrm{mg} / \mathrm{l}$. In 50 healthy control subjects (33 men/17 women, age $38 \pm 2$ years) the mean \pm SEM for SAA was $2.1 \pm 0.5 \mathrm{mg} / \mathrm{l}$ and for CRP $2.7 \pm 0.5 \mathrm{mg} / \mathrm{l}$. Serum amyloid $\mathrm{P}$ protein (SAP) was measured by radial immunodiffusion by using pure SAP [18] as standard and polyclonal antibodies to SAP (Dako, Copenhagen, Denmark). The reference range for SAP is $30-50 \mathrm{mg} / \mathrm{l}$. The sensitivity of the assay is $10 \mathrm{mg} / \mathrm{l}$. The concentration of soluble tumour necrosis factor$\alpha$ Type II receptor (sTNFRII) was determined with a commercially available solid phase enzyme immunoassay (ELISA; Biosource International, Camarillo, Calif., USA).

Statistical analysis. The statistical differences between baseline, at the end of therapy and after the cessation of therapy were calculated using Wilcoxon's signed test and between the 
Table 2. The effect of placebo and troglitazone treatment on various laboratory variables

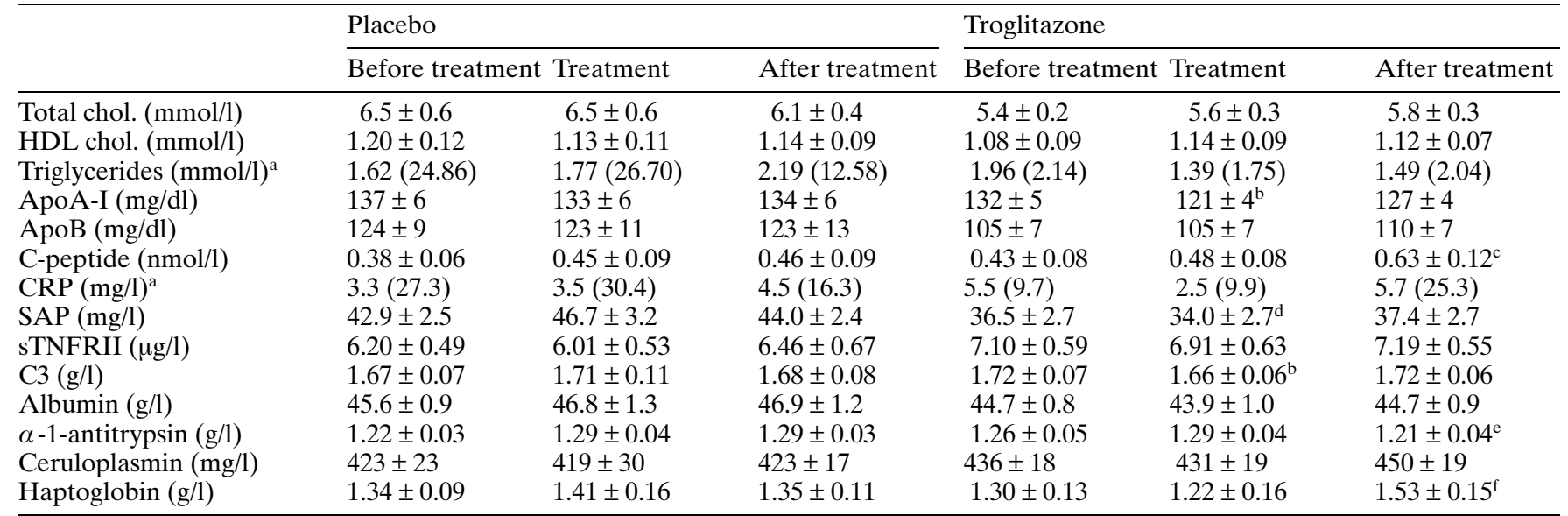

${ }^{\mathrm{a}}$ skewed data, median and range given, ${ }^{\mathrm{b}} p<0.05$ vs before treatment, ${ }^{\mathrm{c}} p<0.01$ vs before treatment and $p<0.05$ vs treatment, ${ }^{\mathrm{d}} p<0.05$ vs after treatment and $p<0.05$ vs placebo,
${ }^{\mathrm{e}} p<0.05$ vs treatment, ${ }^{\mathrm{f}} p=0.001$ vs before treatment and $p<0.001$ vs treatment groups using the Mann-Whitney U-test. The correlation analysis was done with Spearman's test. $P$ value less than 0.05 was considered statistically significant. The results are given as mean \pm SEM.

\section{Results}

The patient characteristics of both groups at randomization are given in Table 1 . At baseline in all the patients mean C3 (1.69 $\pm 0.05 \mathrm{~g} / \mathrm{l})$ was above the reference range and SAA concentration $(6.19 \pm 1.05 \mathrm{mg} / \mathrm{l})$ was almost threefold in comparison with our reference subjects $(p<0.001)$. The baseline laboratory values for both treatment groups are given in Table 2. The baseline $\mathrm{C} 3$ concentration was positively associated with $\mathrm{BMI}(r=0.43, p<0.05)$ and $\mathrm{HbA}_{1 \mathrm{c}}$ $(r=0.63, p<0.01)$. Body mass index correlated also with A1GP $(r=0.51, p<0.01)$ and haptoglobin $(r=0.45, p<0.02)$. The TNFRII concentration was inversely associated with serum HDL-cholesterol $(r=-0.68, p<0.001)$ and directly with serum triglyceride concentration $(r=0.49, p<0.02)$.

At the end of the treatment fasting plasma glucose concentrations $(11.7 \pm 1.3 \mathrm{mmol} / \mathrm{l})$ and $\mathrm{HbA}_{1 \mathrm{c}}$ values $(8.7 \pm 0.3 \%)$ in the placebo group remained unchanged, although daily insulin dose was increased (to $81 \pm 10 \mathrm{U} /$ day, $p<0.05$ vs baseline). In the group treated with troglitazone plasma glucose $(8.1 \pm 0.5 \mathrm{mmol} / \mathrm{l}, \quad p<0.01$ vs baseline $), \quad \mathrm{HbA}_{1 \mathrm{c}}$ $(7.5 \pm 0.3 \%, p<0.01$ vs baseline and $<0.05$ vs placebo) and insulin dosage (63 $\pm 10 \mathrm{U} /$ day $p<0.05$ vs baseline) were reduced at the end of the treatment, whereas BMI rose (to $33.5 \pm 1.3 \mathrm{~kg} / \mathrm{m}^{2}, p<0.01 \mathrm{vs}$ baseline). At the follow-up visit plasma glucose concentration returned to that before treatment $(10.6 \pm 0.7 \mathrm{mmol} / \mathrm{l}, p<0.01 \mathrm{vs}$ treatment $)$.
During troglitazone treatment SAA (Fig.1), A1GP (Fig. 2) and C3 (Table 2) decreased and returned to baseline concentration after the treatment. Apoliprotein A-I decreased during troglitazone therapy. In the placebo group the levels of all variables remained unchanged during the treatment and followup (Table 2). In the group treated with troglitazone the concentration of SAP and haptoglobin were increased and the concentration of $\alpha$-1-antitrypsin decreased from the treated state at the follow-up visit, although no statistically significant change had occurred during the treatment (Table 2). All the measured inflammatory variables were stable in our patients in the untreated states. $\alpha$-1-antitrypsin $(r=0.56$, $p<0.01)$, CRP $(r=0.60, p=0.001)$, SAA $(r=0.76$, $p<0.001)$, SAP $(r=0.75, p<0.001)$, A1GP $(r=0.84$, $p<0.001)$, albumin $(r=0.84, p<0.001)$, ceruloplas$\min (r=0.86, \quad p<0.001)$, haptoglobin $(r=0.86$, $p<0.001)$ and C3 $(r=0.90, p<0.001)$ concentrations at the follow-up visit were closely related to baseline values for the whole group. Serum amyloidA was higher in women than men both before $(7.5 \pm 1.6 \mathrm{mg} / \mathrm{l}$ vs $4.3 \pm 1.0 \mathrm{mg} / \mathrm{l}, p<0.05)$ and after the treatment $(9.6 \pm 1.8$ vs $4.0 \pm 0.8 \mathrm{mg} / \mathrm{l}, p<0.05)$. Also C3 concentrations were higher in women than men both before $(1.78 \pm 0.07 \mathrm{~g} / \mathrm{l}$ vs $1.57 \pm 0.06 \mathrm{~g} / \mathrm{l}$, $p<0.05)$ and after $(1.78 \pm 0.07 \mathrm{~g} / 1$ vs $1.58 \pm 0.04 \mathrm{~g} / \mathrm{l}$, $p<0.05)$ the treatment despite similar BMIs in women $\left(32.9 \pm 1.2 \mathrm{~kg} / \mathrm{m}^{2}\right)$ and men $\left(32.4 \pm 1.1 \mathrm{~kg} / \mathrm{m}^{2}\right)$ at baseline and during the study. Conversely SAP values were higher in men than women both before $(43.2 \pm 2.0 \mathrm{mg} / \mathrm{l}$ vs $36.7 \pm 2.9 \mathrm{mg} / \mathrm{l}, p<0.05)$ and after the treatment $(45.8 \pm 1.6 \mathrm{mg} / \mathrm{l}$ vs $36.5 \pm 2.7 \mathrm{mg} / \mathrm{l}$, $p<0.05)$, respectively. Concentrations of many, but not all, acute-phase proteins in the whole group were associated with each other before the treatments (Table 3). 


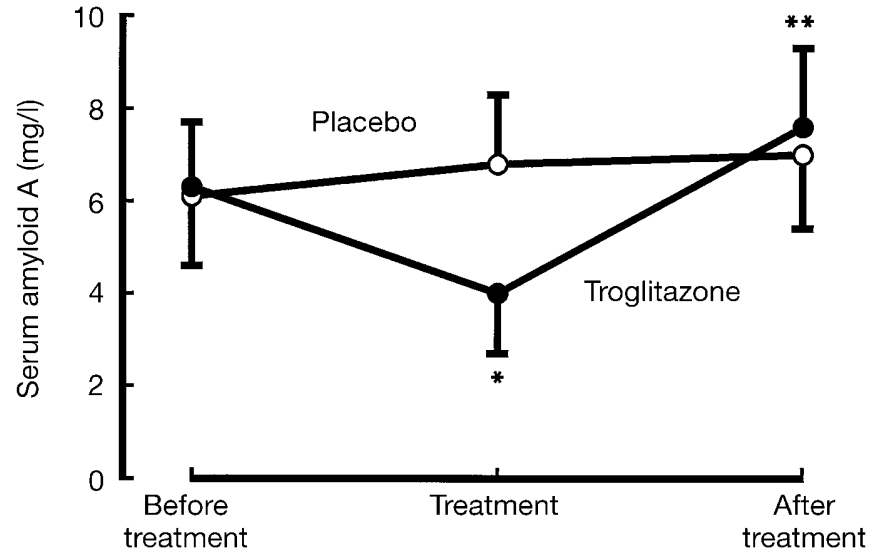

Fig. 1. Serum amyloid A protein concentration before, at the end and after the discontinuation of troglitazone or placebo therapy. $* p=0.001$ vs before treatment, $p<0.05$ vs placebo, $* * p<0.01$ vs at the end of treatment

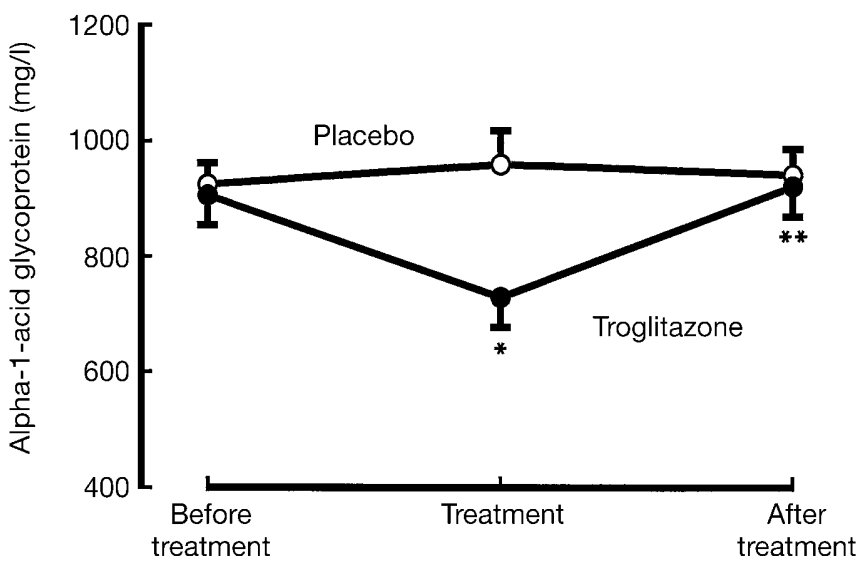

Fig. 2. Serum $\alpha$-1-acid glycoprotein concentration before, at the end and after the discontinuation of troglitazone or placebo therapy. ${ }^{*} p=0.001$ vs before treatment, $p<0.05$ vs placebo, $* * p<0.001$ vs at the end of treatment

\section{Discussion}

In the current study we examined the anti-inflammatory action of a PPAR $\gamma$ agonist in patients with Type II diabetes. In addition, we examined, if the inflammatory factors and their alterations are associated with changes in glucose or lipid metabolism. Serum amyloid $\mathrm{A}$ is a sensitive marker of inflammation [19] and it is increased in patients with Type II diabetes [2]. Complement protein C3 was measured because it is a cytokine-inducible acute-phase plasma protein [20] and vital to all three complement activation pathways and defence against invading micro-organisms [21]. It is synthesized also in the adipose tissue [22] and has a connection to lipid metabolism through its cleavage product acylation stimulating protein (ASP) [23]. It has a critical role in triacylglycerol (TG) synthesis within adipocytes [23]. Serum amy- loid P (SAP) is structurally closely related to CRP [24]. In humans it is not considered an acute-phase protein but is more regarded as a factor of the innate immune system. Both CRP and SAP can activate the classical pathway of the complement system and opsonize invading micro-organisms [24, 25]. Haptoglobin, ceruloplasmin, A1GP and $\alpha$-1-antitrypsin are positive and albumin negative acute-phase proteins [24].

The main findings of our study are: Firstly, the acute-phase reactants SAA [19] and C3 [20] are increased in our Type II diabetic patients. Secondly, troglitazone treatment selectively reduces some acute-phase proteins and $\mathrm{C} 3$ but not others in conjunction with the improvement in glucose metabolism. Thirdly, the concentrations of acute-phase serum proteins are stable at least for almost 5 months in patients with Type II diabetes.

Raised C3 concentration in our patients with Type II diabetes is probably a marker of the inflammation and the activation of the innate immune system. This idea is supported by the increase in serum amyloid A protein concentration observed in this study and in acute-phase proteins reported previously $[1,2]$. We have recently shown raised $\mathrm{C} 3$ concentrations in obese non-diabetic and Type II diabetic patients. In both groups there was an inverse association between insulin sensitivity and serum $\mathrm{C} 3$ protein concentration [5]. In the current study $\mathrm{C} 3$ was positively associated with BMI as also reported previously [26]. If there is a causal relation between glucose metabolism and $\mathrm{C} 3$ protein content, the correlation between serum $\mathrm{C} 3$ protein concentration and glucose disposal rate [5], or with $\mathrm{HbA}_{1 \mathrm{c}}$ in the present study, suggests that the inflammatory reaction contributes to insulin resistance and hyperglycaemia. The design of this study does not allow us to draw conclusions on the possible abnormality of the concentrations of the other acute-phase serum proteins measured (haptoglobin, ceruloplasmin, A1GP and $\alpha$-1-antitrypsin), the mean concentrations of which were inside the reference range for our laboratory.

Increased CRP concentration is a risk factor for cardiovascular disease [3]. In our patients it was increased as reported before [1]. It is possible that this reflects inflammation, which is associated with at least two components of the metabolic syndrome; Type II diabetes and macrovascular disease. Both of these are also characterized by insulin resistance. We measured sTNFRII because it is raised in obesity [27] and follows changes in circulating TNF- $\alpha$ [28]. There was a direct correlation between sTNFRII and serum triglyceride concentration and inverse association with HDL-cholesterol. As high serum triglyceride and low HDL-cholesterol concentrations occcur during insulin resistance, these associations with sTNFRII could be another reflectance of insulin resistance. 
Table 3. Correlation coefficients between concentrations of different serum proteins before the treatments

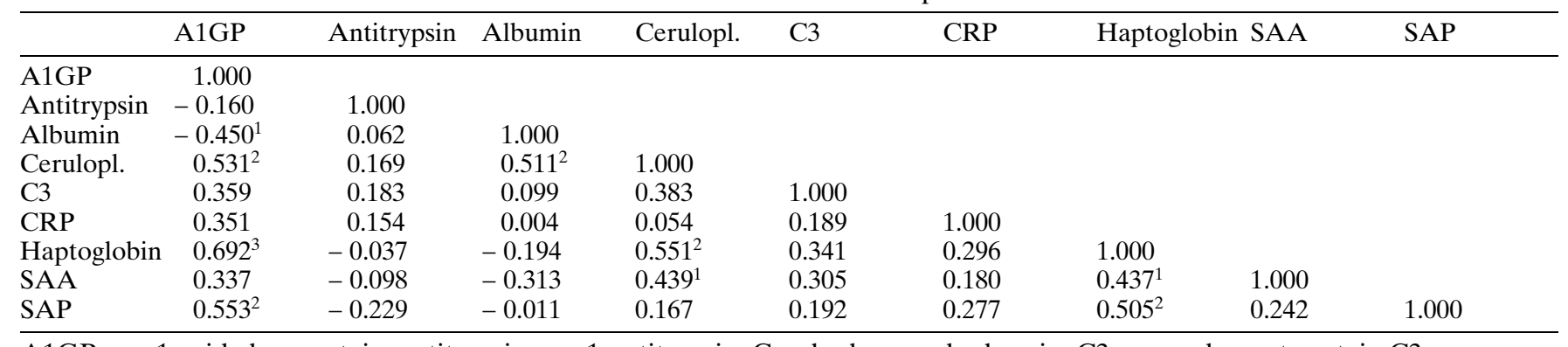

$\mathrm{A} 1 \mathrm{GP}=\alpha$-1-acid glycoprotein, antitrypsin $=\alpha$-1-antitrypsin, Cerulopl. $=$ ceruloplasmin, $\mathrm{C} 3=$ complement protein $\mathrm{C} 3$, $\mathrm{CRP}=\mathrm{C}$-reactive protein, $\mathrm{SAA}=$ serum amyloid $\mathrm{A}, \mathrm{SAP}=$ serum amyloid $\mathrm{P}$ protein. ${ }^{1} p<0.05,{ }^{2} p<0.01,{ }^{3} p<0.001$

Troglitazone treatment increased insulin sensitivity, as was seen from the lower glucose concentrations and $\mathrm{HbA}_{1 \mathrm{c}}$ values in the face of reduced insulin requirements. This is a well known effect of troglitazone $[6,7]$. In the placebo group the metabolic control remained unchanged, although the insulin dose was increased. After cessation of the treatment the glucose concentrations returned to those before treatment, also in the troglitazone group. Troglitazone reduced SAA concentration by $35 \%$. This effect was reversible and returned to baseline after discontinuance of the therapy. Although SAA is a major acutephase reactant with the potential to rise to 1000 -fold over normal concentrations [24], it was very stable in our patients during the almost 5 months of the study. In the placebo group it remained practically unchanged throughout the study and in the troglitazone group it returned to the baseline concentration in 3 weeks (Fig. 1). Also A1GP (Fig. 2) and C3 (Table 2) concentrations decreased in the troglitazone group significantly. Because C3 [26] and also A1GP in this study were positively associated with BMI, the increase in body weight in our patients treated with troglitazone could have prevented an even greater fall in C3 and A1GP concentration caused by troglitazone. Also serum C3 and A1GP concentrations were very stable in our patients in the untreated state. The $25 \%$ reduction in CRP during troglitazone therapy was of borderline significance $(p=0.07)$. Although SAP is not usually considered an acute-phase protein its concentrations increased slightly after the end of troglitazone therapy (Table 2).

The acute-phase response is not a homogeneous reaction but the different proteins are increased or reduced depending on the stimulus [24]. Although $\alpha-1$ antitrypsin, ceruloplasmin and haptoglobin are positive and albumin is a negative acute-phase serum protein, their concentrations were not statistically significantly changed during troglitazone therapy. This suggests that the effect of troglitazone is selective.

Our data are in good agreement with the previous reports on raised acute-phase plasma proteins in Type II diabetes [1, 2]. Because of reports that acute-phase proteins increase with age and our refer- ence values for SAA and CRP were measured in younger people, age could partly explain the high concentrations of SAA and CRP in our patients. The concentrations of SAA and CRP in our patients were, however, more than double that found in control subjects and there was no correlation between age and SAA or CRP in our patients. This suggests that most of the increases in SAA and CRP were due to their diabetic state. In addition to confirming the raised serum amyloid A concentrations, we have added C3 to the list of increased acute-phase plasma proteins in insulin-resistant patients with Type II diabetes. Previously slightly increased C3 concentration with great individual variation [29] has been reported in patients with apparently milder Type II diabetes. We have shown in an earlier study that serum C3 concentration is inversely related to insulin sensitivity in patients with Type II diabetes even after adjustment for BMI [5]. Inflammatory cytokines are the main inducers of acute-phase plasma proteins [24]. Thiazolidinediones have inhibitory effects in vitro on the production of inflammatory cytokines [12, 13], and the reduction in muscle TNF- $\alpha$ could precede the beneficial effects of thiazolidinediones on glucose and lipid metabolism in the rat [14]. Our study shows that troglitazone has a selective reversible effect on some acute-phase serum proteins and C3 in humans. The study also suggests that the inflammatory condition in Type II diabetes is innate and not induced by a bacterial infection. Troglitazone has no effect on cytokine production induced by bacterial lipopolysaccharide [13].

The relevance of increased serum C3 concentration in Type II diabetes is currently not known. Complement protein $\mathrm{C} 3$ is, however, indispensable to all three complement activation pathways [21] and it is also synthesized in the adipose tissue [22]. Its cleavage product acylation stimulating protein [23] has a pivotal function in triglyceride synthesis within adipocytes [23]. Its other split product $\mathrm{C} 3 \mathrm{~d}$ is raised in Type II diabetic patients with ischaemic heart disease or increased albumin excretion rate but normal in patients without these complications [30]. Concentrations of $\mathrm{C} 3$ and $\mathrm{C} 3 \mathrm{~d}$ are not correlated in patients 
with inflammatory diseases [31]. The slight increase in serum amyloid $\mathrm{P}$ concentration after the cessation of troglitazone could also reflect an association between the innate immune system and insulin resistance. The inhibitory effect of serum amyloid $\mathrm{P}$ on haemagglutination induced by influenza A virus is reduced by $N$-acetyl-D-glucosamine [25] and glucosamine plays a central part in the insulin resistance syndrome [32].

Taken together, our study provides evidence for the activation of the innate immune system and inflammation in patients with Type II diabetes. Using a PPAR $\gamma$ agonist, we were able to selectively reduce some acute-phase serum proteins and improve glucose metabolism and insulin sensitivity.

Acknowledgements. We would like to thank E. Koivisto and T. Kyöstiö-Renvall for their valuable help. The grant support from Glaxo Wellcome, Yrjö Jahnsson Foundation, Research Foundation of Orion Corporation, the Maud Kuistila Foundation and Paulo Foundation is acknowledged.

\section{References}

1. McMillan DE (1989) Increased levels of acute-phase serum proteins in diabetes. Metabolism 38: 1042-1046

2. Pickup JC, Mattock MB, Chusney GD, Burt D (1997) NIDDM as a disease of the innate immune system: association of acutephase reactants and interleukin-6 with metabolic syndrome $\mathrm{X}$. Diabetologia 40: 1286-1292

3. Alexander RW (1994) Inflammation and coronary artery disease. N Engl J Med 331: 468-469

4. Spiegelman BM, Flier JS (1996) Adipogenesis and obesity: rounding out the big picture. Cell 87: 377-389

5. Koistinen HA, Koivisto VA, Ebeling P (1998) Serum complement protein $\mathrm{C} 3$ is a marker of insulin resistance, which is related to obesity, but not to hyperglycemia. Diabetes 47 [Suppl 1] A311

6. Nolan JJ, Ludvik B, Beerdsen P, Joyce M, Olefsky J (1994) Improvement in glucose tolerance and insulin resistance in obese subjects treated with troglitazone. $\mathrm{N}$ Engl J Med 331: 1188-1193

7. Suter SL, Nolan JJ, Wallace P, Gumbiner B, Olefsky JM (1992) Metabolic effects of new oral hypoglycemic agent CS-045 in NIDDM patients. Diabetes Care 15: 193-203

8. Lehmann JM, Moore LB, Smith-Oliver TA, Wilkison WO, Willson TM, Kliewer SA (1995) An antidiabetic thiazolidinedione is a high affinity ligand for peroxisome proliferator-activated receptor $\gamma$ (PPAR $\gamma$ ). J Biol Chem 270: 12953-12956

9. Forman BM, Tontonoz P, Chen J, Brun RP, Spiegelman BM, Evans RM (1995) 15-deoxy- $\Delta^{12,14}$-prostaglandin $\mathbf{J}_{2}$ is a ligand for the adipocyte determination factor $\operatorname{PPAR} \gamma$. Cell 83: 803-812

10. Kliewer SA, Lenhard JM, Willson TM, Patel I, Morris DC, Lehmann JM (1995) A prostaglandin $\mathrm{J}_{2}$ metabolite binds peroxisome proliferator-activated receptor $\gamma$ and promotes adipocyte differentiation. Cell 83: 813-819

11. Willson TM, Cobb JE, Cowan DJ et al. (1996) The structureactivity relationship between peroxisome proliferator-activated receptor $\gamma$ agonism and the antihyperglycemic activity of thiazolidinediones. J Med Chem 39: 665-668

12. Ricote M, Li AC, Willson TM, Kelly CJ, Glass CK (1998) The peroxisome proliferator-activated receptor- $\gamma$ is a negative regulator of macrophage activation. Nature 391: 79-82
13. Jiang C, Ting AT, Seed B (1998) PPAR- $\gamma$ agonists inhibit production of monocyte inflammatory cytokines. Nature 391: $82-86$

14. Murase K, Odaka H, Suzuki M, Tayuki N, Ikeda H (1998) Pioglitazone time-dependently reduces tumour necrosis factor- $\alpha$ level in muscle and improves metabolic abnormalities in Wistar fatty rats. Diabetologia 41: 257-264

15. Spiegelman BM (1998) PPAR $\gamma$ in monocytes: less pain, any gain? Cell 93: 153-155

16. Ebeling P, Tuominen JA, Bourey R, Koranyi L, Koivisto VA (1995) Athletes with IDDM exhibit impaired metabolic control and increased lipid utilization with no increase in insulin sensitivity. Diabetes 44: 471-477

17. Honkanen E, Grönhagen-Riska C, Teppo A-M, Maury CPJ, Meri S (1991) Acute-phase proteins during hemodialysis: correlations with serum interleukin- $1 \beta$ levels and different dialysis membranes. Nephron 57: 283-287

18. Andersen JK, Mole JE (1982) Large scale isolation and partial primary structure of human plasma amyloid P-component. Ann N Y Acad Sci 389: 216-234

19. Maury CPJ (1985) Comparative study of serum amyloid A protein and C-reactive protein in disease. Clin Sci 68: 233-238

20. Baumann H, Morella KK, Wong GHW (1993) TNF- $\alpha$, IL-1 $\beta$ and hepatocyte growth factor cooperate in stimulating specific acute-phase plasma protein genes in rat hepatoma cells. J Immunol 151: 4248-4257

21. Thiel S, Vorup-Jensen T, Stover CM et al. (1997) A second serine protease associated with mannan-binding lectin that activates complement. Nature 386: 506-510

22. Choy LN, Rosen BS, Spiegelman BM (1992) Adipsin and an endogenous pathway of complement from adipose cells. J Biol Chem 267: 12736-12741

23. Cianflone K, Roncari DAK, Maslowska M, Baldo A, Forden J, Sniderman AD (1994) Adipsin / acylation stimulating protein system in human adipocytes: regulation of triacylglycerol synthesis. Biochemistry 33: 9489-9495

24. Steel DM, Whitehead AS (1994) The major acute-phase reactants; C-reactive protein, serum amyloid $\mathrm{P}$ component and serum amyloid A protein. Immunol Today 15: 81-88

25. Andersen O, Vilsgaard Ravn K, Juul Sørensen I, Jonson G, Holm Nielsen E, Svehag S-E (1997) Serum amyloid P component binds to influenza A virus haemagglutinin and inhibits the virus infection in vitro. Scand J Immunol 46: 331-337

26. Pomeroy C, Mitchell J, Eckert E, Raymond N, Crosby R, Dalmasso AP (1997) Effect of body weight and caloric restriction on serum complement proteins, including Factor D/adipsin: studies in anorexia nervosa and obesity. Clin Exp Immunol 108: 507-515

27. Hotamisligil GS, Arner P, Atkinson RL, Spiegelman BM (1997) Differential regulation of the p80 tumour necrosis factor receptor in human obesity and insulin resistance. Diabetes 46: 451-455

28. Jacobson JM, Greenspan JS, Spritzler J et al. (1997) Thalidomide for the treatment of oral aphthous ulcers in patients with human immunodeficiency virus infection. N Engl J Med 336: $1487-1493$

29. Krantz S, Stelter F, Lober M, Rjasanowski I, Michaelis D, Buske B (1988) Complement component 3 (C3) and diabetes mellitus. Exp Clin Endocrinol 92: 287-296

30. Figueredo A, Ibarra JL, Bagazgoitia J et al. (1993) Plasma C3 d levels and ischemic heart disease in type II diabetes. Diabetes Care 16: 445-449

31. Mollnes TE (1985) Quantification of the C3d split products of human complement by a sensitive enzyme-linked immunosorbent assay. Scand J Immunol 21: 607-613

32. Hawkins M, Barzilai N, Liu R, Hu M, Chen W, Rossetti L (1997) Role of the glucosamine pathway in fat-induced insulin resistance. J Clin Invest 99: 2173-2182 